\title{
Psalm 54: The power of positive patterning ${ }^{1}$
}

\author{
P J Botha \\ (University of Pretoria)
}

\section{ABSTRACT}

\section{Psalm 54: The power of positive patterning}

Psalm 54 is analysed in ' $n$ literary, rhetorical and socio-critical way in order to determine the dominant textual strategy and the way in which it was supposed to function. It is established that the basic concern of the psalm is with the honour of the individuals for whom the psalm was intended as a cultic prayer. The way in which words with a positive and those with a negative connotative meaning are arranged, is found to be compliant with the purpose of having the enemies exposed and the self vindicated. What is more, this pattern seems to have been devised also to be of therapeutic value for the suppliant himself.

\section{INTRODUCTION}

Psalm 54 is a typical lament of the individual ${ }^{2}$, displaying all the usual features of petition; lamentation; declaration of trust; the giving of a vow and thanksgiving (Weiser 1955:280). It has been described as showing "a simple and lucid structure"3. But there seems to be more to the poem than meets the eye at first glance. On a different level, that of connotative meaning, it seems to portray an intricate pattern that proceeds from positive feeling to negative feeling within each subsection. An analysis that probes this pattern may provide a clue to the way in which the poem was meant to function as a persuasive prayer, but simultaneously as an instrument of pastoral care. It may be possible to detect the process through which an afflicted follower of Yahweh was guided to reconcile positive and negative influences in his or her life in

\footnotetext{
1 This article is dedicated to Professor Wil Vosloo. He knowingly taught me Old Testament theology and unwittingly a lot of Christian praxis. I completed a dissertation of limited scope under his guidance and came to admire his eventemperedness, his friendliness, his capacity for hard and thorough work and his ability to put thoughts into words very much. I wish to thank him for that influence and for the many projects in which I had the privilege of participating under his guidance since then.

${ }^{2}$ It is considered by some to be a model of the genre of individual laments. Cf Van der Ploeg (1973:330). Others, such as Briggs (1925:16-17) assume it to be a prayer for national victory from the time of Josiah.

${ }^{3}$ German: "einen einfachen, klaren Aufbau" (Weiser 1955:280). Quoted from the English translation of Weiser's commentary, Weiser (1962:415). Auffret (1993:15) sees a complex pattern comprising a parallelism and a chiasm in the whole of the psalm.
} 
order to reach catharsis. The procedure will be to segmentise and analyse the poem first in a stichometric way and then, within these parameters, try to analyse also its emotional oscillation.

\section{STICHOMETRIC ANALYSIS}

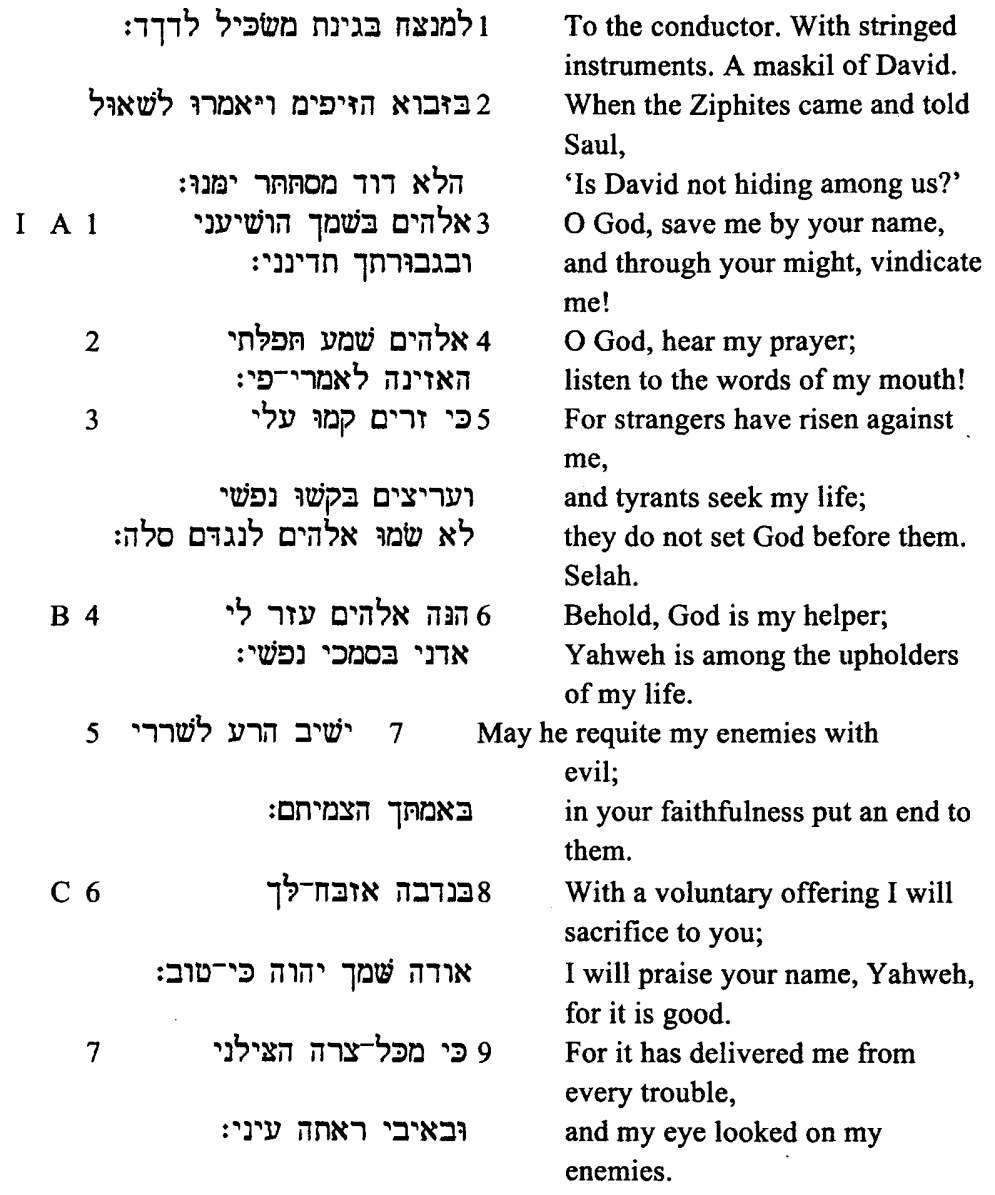

In the stichometric segmentation presented above, the elements of petition and lamentation have been grouped together in one strophe (A). It is necessary to include verse 5 (comprising verse line 3 , numbered to the left of the text) in the first strophe, since it is introduced by the causal particle $כ$, linking the lament about murderous enemies closely to 
the petition for help and hearing ${ }^{4}$. The second strophe (B) then comprises the declaration of trust and a request for the destruction of his enemies, while the third and last strophe comprises the vow and thanksgiving (strophe C). The last verse line is again linked to the previous one through an introductory $\supset$, and most commentators agree about the structural combining of verses 6 and 7 and verses 8 and 9 respectively (Weiser 1955:280). The heading of the psalm is an obvious later prose addition and is not considered to be a part of the poem, although it is indeed a part of the text of Psalm 54 $4^{5}$.

The poem displays some fine examples of parallelism, especially in the first strophe. Verse line 1 comprises a five-fold internal parallelism; verse line 2 is a three-fold internal parallelism; while these two verse lines also form an external parallelism in which at least three elements are repeated אלהימ, imperatives and first person singular pronominal suffix). Verse line 3 is a tristichic line in which the first two feet have three parallel elements. The verb of the central foot is also parallel to that of the last; while the preposition plus suffix of the first and last feet form another parallel. All the other verse lines $(4,5,6$ and 7) are constructed with two or three elements in parallel. There is not an excess of other poetic tropes, yet the repetition of certain elements, combined with the simplicity of diction, provides a certain beauty to the psalm. The parallel elements in the first verse line provide alliteration and rhyme. The last words of the two hemistichs of the second verse line provide assonance and the words שמו in verse line 3 are another instance of assonance. There are more instances of assonance in line 4 and of rhyme in lines 6 and 7. It is interesting to note that the poem begins with two lines ending in e:ni and ends with lines ending in ani and éni respectively. This draws attention to the fact that the prayer of the opening line ("O God, save me by your name") has changed to the words of thanking ("For it [your name] has delivered me from every trouble...") at the beginning of the last line. This is a clear case of inclusio ${ }^{6}$.

\section{THE CONNOTATIVE PATTERN}

To elaborate somewhat on the idea of inclusio, there seems to be an interesting pattern of connotative values in the poem. If the verbs and

${ }^{4}$ Anderson (1985:408); Weiser (1955:280) and Van der Ploeg (1973:330) suppose verse 5 to stand on its own. Others (for example, Seybold 1996:219) group verse 5 toegether with verses 3 and 4 .

5 According to Weiser (1955:280) the heading was inserted because of the correspondence between verse 5 and 1 Sam 23:15 and was taken from 1 Sam 23:19.

${ }^{6}$ So also Van der Ploeg (1973:330). 
nouns are marked with either a positive or a negative sign according to the most probable emotive quality of $\operatorname{each}^{7}$, it renders the following pattern:

O God $(+)$, save $(+)$ me by your name $(+)$, and through your might $(+)$, vindicate $(+)$ me.

O God $(+)$, hear $(+)$ my prayer $(+)$;

listen $(+)$ to the words $(+)$ of my mouth $(+)$ !

For strangers (-) have risen (-) against (-) me, and tyrants $(-)$ seek $(-)$ my life $(+)$;

they do not $(-)$ set $(+)$ God $(+)$ before them.

Behold, God $(+)$ is my helper $(+)$;

Yahweh $(+)$ is among the upholders $(+)$ of my life $(+)$.

May he requite (-) my enemies $(-)$ with evil (-);

in your faithfulness (+) put and end (-) to them.

With a voluntary offering $(+)$ I will sacrifice $(+)$ to you;

I will praise $(+)$ your name $(+)$, Yahweh $(+)$, for it is good $(+)$.

For it has delivered $(+)$ me from every trouble $(-)$,

and my eye $(+)$ looked on $(+)$ my enemies $(-)$.

In summarised form:

$[(+)(+)(+)]=(+)$ Imperative (prayer)

$[(+)(+)]=(+) \quad$ Imperative

$[(+)(+)(+)]=(+) \quad$ Imperative

$[(+)(+)(+)]=(+) \quad$ Imperative

$[(-)(-)(-)]=(-) \quad$ Indicative perfect $3 \mathrm{pl}$ (reason)

$[(-)(-)(+)]=(-) \quad$ Indicative perfect $3 \mathrm{pl}$

$[(-)(+)(+)]=(-) \quad$ Indicative perfect $3 \mathrm{pl}$

$[(+)(+)]=(+) \quad$ Indicative participle (trust)

$[(+)(+)(+)]=(+) \quad$ Indicative participle

$[(-)(-)(-)]=(+) \quad$ Jussive $3 \mathrm{~m} \mathrm{~s}$ (prayer)

$[(+)(-)]=(+) \quad$ Imperative

7 The connotative quality of most of these verbs and nouns is unambiguous; in some cases there may be doubt. When they are judged in terms of the core social values of honour and shame, the value chosen here should be more evident. 

$[(+)(+)]=(+)$
Indicative imperfect $1 \mathrm{~s}$ (vow)
$[(+)(+)(+)(+)]=(+)$
Indicative imperfect $1 \mathrm{~s}$
$[(+)(-)]=(+)$
Indicative perfect $3 \mathrm{~ms}$ (reason)
$[(+)(+)(-)]=(+)$
Indicative perfect $3 \mathrm{f} \mathrm{s}$

What is striking about this pattern, is the fact that the beginning of each section is overwhelmingly positive in outlook. Negative terms are only used in the second half of each strophe, and only the second half of the first strophe can be described as negative altogether. In the second and third strophe, the negative terms are used in a positive context or with a positive purpose. The effect of all this is that this hymn, although it is a lament, exudes a positive mood. The transition from a positive to a negative or a mixed positive and negative section is also introduced in both the first and the last strophe by the particle כי.

\section{THE TEXTUAL STRATEGY OF PSALM 54}

The question that now concerns the researcher of this psalm is to describe how it was supposed to function as a means of communication. The more important literary aspects have been discussed, but this must be correlated with the social dimensions of the text. The strategy of a text can usually be deduced from its genre, stressed ideas, dominant terms and semantic fields, traditions employed, syntactical arrangement, line of argumentation, and the shared goals, values, norms, sanctions, and traditions to which appeal is made (cf Elliott 1993:73). A good starting point is to list the role players in the text. These consist of the implied author, the implied suppliant, and the implied audience ${ }^{8}$. This distinction is made on the assumption that the real author created the prayer for cultic use by later suppliants (an implied suppliant). The implied audience would include God to whom the prayer would be directed and all those who would possibly hear the prayer (friends, neutral bystanders as well as the enemies mentioned in the prayer itself) (Coetzee 1999:402-403). If the enemies were included in the implied audience, a prayer such as this psalm would constitute a challenge in the challenge-and-response interaction of a society in which honour and shame formed the core values ${ }^{9}$. Utterances that were directed at God then become double-duty requests for help and claims to honour.

\footnotetext{
${ }^{8}$ In this and the following analysis, I gratefully acknowledge the insights I gained through reading the article of Johan Coetzee (1999:401-415). For a similar analysis of Psalm 3, cf pp 402-403 of his article.

${ }^{9}$ Included are all communities bordering on the Mediterranean Sea in ancient times. Cf Malina (1981:25-50).
} 
In the case of Psalm 54, it may be objected that the enemies are (inter alia) called "strangers" ( $v 5$ ) and that such a term could not be used of those sharing the same cultic area ${ }^{10}$. However, calling the adversaries all kinds of names, even implying that they are not Yahwehfollowers, would be a fair practice in such an altercation. The opponents are called strangers (זרים), (זריצים), people who do not set God before them, adversaries (שררים), and enemies (איבים). By stating that they "do not set God before them", the religious orientation and evil intentions of the enemies are exposed. The (implied) author is supplying the implied suppliant with a prayer that would fit his situation more or less adequately in vindicating himself ${ }^{11}$ and in challenging the honour of the adversaries. If they were real strangers, there would be no challenge to the honour of the suppliant and the prayer would function merely as a request for help. But the references to justice ("vindicate" and "requite") indicate that the enemies were indeed members of the same society ${ }^{12}$. It seems reasonably clear that the values to which the author of Psalm 54 makes an appeal are the core values of honour and shame. The honour of Yahweh plays an important part in the drama. His "name" is a replication of his honour. When the implied suppliant uses the phrase "save me by your name", the implication is that Yahweh must act for the sake of his own honour ${ }^{13}$. The suppliant is claiming an intimate relationship with Yahweh. His honour is challenged and he turns to Yahweh to "vindicate" his honour ${ }^{14}$. If Yahweh fails to do so, his power to act (note the parallel use of "might" in verse $3 b$ ) would be questioned by the community and his honour would be diminished ${ }^{15}$. For the same reason, reference is later also made to Yahweh's "faithfulness" (verse $7 b$ ). In claiming a special relationship with Yahweh, the suppliant is implying that no such relationship exists between Yahweh and his enemies. He therefore also states explicitly that "they do not set God

${ }^{10}$ Seybold (1996:54) deduces from this that the psalm was later reworked for use by Israel as a collectivity.

11 It would be improper to add "and herself", since the honour of women would be challenged through that of a guardian, not directly.

12 This is also the interpretation of Weiser (1955:208-281). Van der Ploeg (1973:330) thinks it could either be Israelites or non-Israelites, but adds later on (1973:331) that "strangers" could also be Israelites not belonging to the upright or the social group of the psalmist.

13 This does not indicate that "der göttliche Name eine besondere Wunderkraft besitze" as Weiser (1955:280) would have us to believe.

14 "The righteous person's claim to honor is evidence of [a] special relationship with God because of reliance on God's help (Pss 54; 55)". Cf Plevnik (1998:108).

${ }^{15}$ Power is a means value which facilitates the realisation of the core values of honour and shame. "When subordinates accept and respect the power of superiors, the superior is considered to be honorable". Cf Pilch (1998:158). 
before them". They are men with evil intentions. They "have risen" against the suppliant and they "seek" his life (v 5).

The second strophe, B, begins with again claiming a special relationship to Yahweh. But the first two verse lines of this strophe (v lines 4 and 5; vs 6 and 7) are addressed primarily to the implied audience: "Behold, God is my helper, Yahweh is among the upholders of my life". God is part of his supporters. This claim to a special relationship with Yahweh amounts to a claim to honour for the suppliant himself. $\mathrm{He}$ is also confident that the honour of Yahweh will remain in good stead and that his own honour would be upheld. He already promises to thank God with a voluntary offering and to praise his name, thus to honour him. God's name is "good", honourable, for it will deliver him from "every trouble". He expects his "eye" to look "on" his enemies. This is an expression that explicitly claims honour, since the ability to look onto someone else implies the low position of that person in relation to the one whose eye it is.

If the surmise about the cultic use of the psalm is correct, then the most important shared values that play a role in this psalm are indeed that of honour and shame. These are the core values and either one or both is present in every verse line. The intended impact of the psalm therefore seems to be to confirm the honour of the implied suppliant. This is done by appealing to Yahweh to acknowledge the special relationship between his praying servant and himself and thus to vouch for the honour of his servant. The honour of the opponents is challenged at the same time, since they are called names which imply that they are dishonourable, that they have dishonourable intentions and that they do not honour God (they do not "set" God before them, v 5). The suppliant, on the other hand, acknowledges the honour of Yahweh. He confesses that the honour of Yahweh (his name) has delivered him (the suppliant) from trouble ( $v 9$ ). God is the "helper" of the suppliant and the "upholder" of his life (v 6). Therefore the suppliant will bring sacrifices and will praise the "name" of Yahweh (v 8).

It is with the purpose of strengthening the association between the suppliant and Yahweh, and of increasing the distance between Yahweh and his enemies, that the implied author makes use of the positive and negative connotative patterns in this prayer. The observation made above that the beginning of each strophe is overwhelmingly positive is in fact only a recognition of the fact that Yahweh is addressed in those parts or, otherwise, that his concern for the suppliant is described. At the beginning of Strophes A, B, and C there is a cluster of God-words; at the end of each of these strophes there is a cluster of enemy-words: 

A: $\quad$ God, Name, God
"for" Strangers, Tyrants, Not God.
B: God, Yahweh
Enemies, Evil
C: Name, Yahweh, Good
"for" Trouble, Enemies

The first and second verse lines (vs 3 and 4) begin with the word "God". This is a powerful way of getting the attention of Yahweh and also that of the audience. But it also establishes the pattern of a close association between Yahweh and the suppliant. The first parallelism of the poem is formed in part by the parallel between the second person masculine suffixes and the first person singular suffixes. In the second strophe, the first parallelism is likewise formed between two designations for God and two first person singular suffixes. In the third and last strophe, the first parallelism consists of two instances of the first person singular imperfect prefix and two second person masculine suffixes. The author thus reserves, so to speak, the centre of the stage for Yahweh and the suppliant, while the enemies and their lack of association with God (and their association with evil instead) are relegated to the background. In the first strophe, the association of the enemy with evil is still threatening, while in the second the threat is ended with a reference to Yahweh's action against them. Appropriately, the last word of the strophe is also the one that refers to the "ending" of the enemies. In this instance, the threat is still a possibility, since God's action is requested and not realised. But in the last strophe it is "realised", since the form of the verbs is in the perfect: "(Your name) has delivered me...", "my eye looked on my enemies".

In this way, the association of Yahweh with the suppliant remains a constant element throughout the prayer, while the association of the suppliant with his enemies changes from that of a threatening situation to one from which escape is possible and finally to one where triumph is inevitable. As a prayer, this psalm is therefore not only directed at Yahweh, but also at an audience who must judge the honour of the suppliant, at the enemies who must realise that they had better call their evil deeds off, and at the suppliant himself who must find comfort and victory through the words he chants. 


\section{CONCLUSION}

Psalm 54, a typical lament of the individual, perhaps reveals to the modern researcher who looks at it with the help of a social-scientific analysis, the reasons why certain elements recur so often in such laments ${ }^{16}$. This psalm was not meant merely to communicate the needs and fears of an individual to Yahweh. It was also meant to expose the motives and means of the enemies, to reveal the true honour of the suppliant to the bystanders, and to facilitate a process of catharsis within the afflicted suppliant himself. ${ }^{17}$ This also means that the beautiful parallelisms and other rhetorical devices were not meant merely to adorn the psalm, but were instruments of social and psychological change themselves. Psalm 54 is a means of responding to the challenge brought against one's standing in society, thus one's claim to honour and therefore serves to uphold the balance within the community of believers and within the mind of the afflicted believer himself.

\section{Consulted literature}

Anderson, A A 1985. The Book of Psalms. Vol I (Psalms 1-72). Grand Rapids: Eerdmans. (New Century Bible Commentary).

Auffret, P 1993. Voyez de vos yeux. Étude structurelle de vingt psaumes, dont le psaume 119. Leiden: Brill.

Briggs, E G 1925. A critical and exegetical commentary on the Book of Psalms, Vol. II. Edinburgh: Clark.

Coetzee, J 1999. Retoriese strategieë in Psalm 3. Old Testament Essays 12(3), 401415.

Elliott, J H 1993. What is social-scientific criticism? Minneapolis: Fortress.

Lamparter, H 1961. Das Buch der Psalmen I. Stuttgart: Calwer Verlag.

Malina, B J 1981. The New Testament world. Insights from cultural anthropology. Atlanta: John Knox.

Pilch, J J \& Malina, B J (eds) 1998, Handbook of Biblical social values. Peabody: Hendrickson.

Pilch, J J 1998. Article s v "Power" in: Pilch, J J \& Malina, B J (eds), Handbook of Biblical social values, 158-161.

\footnotetext{
${ }^{16}$ According to Lamparter (1961:270), the sudden change of mood between verses 5 and 6 indicates "da" Gott selbst den Bedrängten durch die Zusage seines machtvollen Beistands getröstet... hat". If the reconstruction in this article is correct, this needs not be the case.

17 The judgement of Weiser (1962:417) that "the worshipper's prayer is... unable to exercise a liberating influence" since it "does not lead on to the uttermost depths of ultimate truth" is harsh and does not take the social context of the psalm into consideration.
} 
Plevnik, J 1998. Article s v "Honor/ Shame" in: Pilch, J J \& Malina, B J (eds), Handbook of Biblical social values, 106-115.

Seybold, K 1996. Die Psalmen. Tübingen: Mohr. (HAT).

Van der Ploeg, J P M 1973. Psalmen. Deel I, Psalm 1 t/m 75. Roermond: J J Romen. (BOT).

Weiser, A 1955. Die Psalmen. Erster Teil: Psalm 1-60. 4. Auflage. Göttingen: Vandenhoeck.

Weiser, A 1962. The Psalms. A commentary. Translated by H Hartwell. London: SCM. (OTL). 